\title{
Education Policy Overcome Coronavirus, A Study of Indonesians
}

\author{
Muh Barid Nizarudin Wajdi \\ STAI Miftahul Ula Nganjuk \\ baridnizar84@gmail.com
}

Iwan Kuswandi

STKIP PGRI Sumenep

iwankus@stkippgrisumenep.ac.id

Umar Al Faruq

UIN Maulana Malik Ibrahim Malang

mazalfa2018@gmail.com

Zulhijra

UIN Raden Fatah Palembang

zulhijra uin@radenfatah.ac.id

Khairudin

IAI Muhammadiyah Bima

ummulkhairat@gmail.com

Khoiriyah

STAI Muhammadiyah Probolinggo

riyaahmad89@gmail.com,

Article History:

Received: Jan $10^{\text {th, }} 2020$

Revised: Feb 13 $13^{\text {th, }} 2020$

Accepted: March 30th, 2020

\section{Abstract}

The COVID-19 or Coronavirus that encircled Indonesia seems to be unmuted. Its massive and relatively fast spread makes people feel scared. Everyone is forced to remain at home to break the COVID-19 transmission chain. Mass agenda eliminated because of COVID-19 also the term work from home (WFH) so popular. COVID-19 also has a serious impact on the education sector in Indonesia. Here are some policies in the world of education taken by the Indonesian government in the emergency period of Coronavirus (COVID-19) year 2020. This article aims to discuss government policy, especially about the education policy to deal with Coronaviruses. The results showed that some government policies related to education in the time Coronavirus could minimize the spread of coronaviruses. These policies include online learning for school 
children, online lectures, national Examinations 2020 canceled, UTBK SBMPTN 2020 postponed, the implementation for SNMPTN still in review

Keyword: Coronavirus, COVID-19, Online Learning, Education Policy

\section{INTRODUCTION}

The impact of the use of Coronavirus (COVID-19) is now also felt by the education world. This has been recognized by the United Nations Education, Scientific and Cultural Organization (UNESCO) on Thursday (5/3), that Coronavirus outbreak has impacted the education sector(UNESCO, 2020). Nearly 300 million students interrupted their school activities around the world and threatened their future education rights(Handoyo, 2020).

The previous day, 13 countries including China, Italy, and Japan had closed schools around the country in an attempt to stop the spread of the virus. It affects nearly 290 million students. Most of the students come from China. Across the country, including Hong Kong and Macao-specific administration areas, more than 233 million students are not schools due to viruses. It was followed by the Japanese, which had nearly 16.5 million students moved(Palu, 2020).

Some schools and universities have been temporarily laid off in their educational activities. One of the campuses in Malaysia, for example, International Islamic University Malaysia (IIUM) decided to postpone the admission time as anticipating the prevention of virus spreading(EdgeProp, 2020). While China's own Ministry of Education extended lunar holidays to schools and their campus. New school year teaching and learning activities that should begin after January 30 or early February are postponed to an undetermined time(Shira, 2020). This is the case in South Korea which also extends its high school holidays(Kim \& Denyer, 2020). In Indonesia, the educational world also feels its impact. A wide range of comparative Foreign Studies Program activities (overseas) should be canceled. This is done after the level of spreading of Coronavirus in Singapore rises from yellow level to orange level. Another activity is the comparative study of overseas to Japan which should depart at the beginning of March to be canceled.

Until now, the condition of spreading the virus is still a concern. The latest Data dissemination of a new type of Coronavirus cause COVID-19 has now been positively confirmed in 84 countries. Data Friday (6/3) morning, noted 97,885 cases of positive infected, with a death rate of 3,348. Meanwhile, a cured patient has reached more than 50 percent of the number of cases or about 53,796. Data will continue to increase(WHO, 2020). If this condition continues to increase, certainly, the impact on the education sector will also increase. The most feared impact is the long term effect. Because students and students will automatically 
feel the delay in the education process it is running. This can lead to the slow growth of their maturity in the future.

Especially if the COVID-19 does not end soon. The policy of delays in schools in the countries affected by the virus can automatically interfere with the right of each of its citizens to obtain proper educational services. The closure of schools and campuses can certainly impede and slow the achievement of targets already set by Governments and/or schools respectively.

Surely, this condition will disrupt the achievement of students ' maturity in achieving their learning objectives, both academically and psychologically. More worrying is its psychological impact. Students who have to be delayed by school closure are very likely to experience psychological trauma that makes them demoting to learning.

Likewise with the cancellation of several important agenda and programs abroad students such as competitions and overseas studies make them disappointed because they feel they have prepared a long-time earlier. Moreover, the students ' insight around coronaviruses is minimal which can make them have higher levels of concern.

This article aims to discuss the Indonesian government policy, especially about the education policy to deal with Coronaviruses.

\section{LITERATURE REVIEW}

\section{Coronavirus}

Coronaviruses are a group of related viruses that cause diseases in mammals and birds. In humans, coronaviruses cause respiratory tract infections that can be mild, such as some cases of the common cold (among other possible causes, predominantly rhinoviruses), and others that can be lethal, such as SARS, MERS, and COVID-19 (Gao et al., 2020; Hageman, 2020; Sun et al., 2020; Velavan \& Meyer, 2020). Symptoms in other species vary: in chickens, they cause an upper respiratory tract disease, while in cows and pigs they cause diarrhea. There are yet to be vaccines or antiviral drugs to prevent or treat human coronavirus infections. Coronaviruses constitute the subfamily Orthocoronavirinae, in the family Coronaviridae, order Nidovirales, and realm Riboviria.(Board, 2020; Laboratory testing of human suspected cases of novel coronavirus (nCoV) infection. Interim guidance, 10 January 2020, n.d.; Novel coronavirus infection, 2013) They have enveloped viruses with a positive-sense single-stranded RNA genome and a nucleocapsid of helical symmetry. The genome size of coronaviruses ranges from approximately 27 to 34 kilobases, the largest among known RNA viruses(Cruz et al., 2011; Geller et al., 2012; Masters, 2006; Sexton et al., 2016; Sturman \& Holmes, 1983). The name coronavirus is derived from the Latin corona, meaning "crown" or "halo", which refers to the characteristic appearance reminiscent of a solar corona around the virions (virus particles) when viewed under two-dimensional 
transmission electron microscopy, due to the surface being covered in club-shaped protein spikes.Coronavirus disease (COVID-19) is an infectious disease caused by a newly discovered coronavirus(Chen et al., 2020; Touret \& de Lamballerie, 2020; Zheng et al., 2020).

Most people infected with the COVID-19 virus will experience mild to moderate respiratory illness and recover without requiring special treatment. Older people and those with underlying medical problems like cardiovascular disease, diabetes, chronic respiratory disease, and cancer are more likely to develop serious illness.

The best way to prevent and slow down transmission is be well informed about the COVID-19 virus, the disease it causes and how it spreads. Protect yourself and others from infection by washing your hands or using an alcohol based rub frequently and not touching your face.

The COVID-19 virus spreads primarily through droplets of saliva or discharge from the nose when an infected person coughs or sneezes, so it's important that you also practice respiratory etiquette (for example, by coughing into a flexed elbow).

At this time, there are no specific vaccines or treatments for COVID-19. However, there are many ongoing clinical trials evaluating potential treatments. WHO will continue to provide updated information as soon as clinical findings become available.

\section{Lockdown Policy Analysis in Corona Virus management}

Lockdown is an emergency protocol to prevent people, groups of people, or communities from being large, leaving or entering from or to an area. Lockdown protocols can only be established by authorities.

In the security context, Lockdown can mean isolating an area. This protocol, overseas, is often applied in schools or in public facilities such as hospitals in the event of a matter of force majeure(Bair, 2002; Jones et al., 2017).

For example, a school or campus in Stanford generally has a Lockdown protocol with many levels, from the Controlled Lockdown (Exit Only), Controlled Lockdown (Entry Only), Partial Lockdown, and Lockdown Department, and Total Lockdown. Lockdown is also done with the prohibition of holding meetings involving many people, closing schools, and public places. Thus, the risk of a corona virus transmission in communities outside the lockdown region can be reduced(Babic et al., 2019; Weil, 2003).

In the case of Corona, Lockdown has the similarity of meaning in the term quarantine region, as stipulated in Law No. 6 of 2018 on the health significance(UURI, 2018).

In the act it is mentioned that:

"Regional quarantine is a resident restriction on an area including the entrance of the entry and its contents allegedly infected with disease and/or contaminated in such a way as to prevent the possibility of spreading the disease or contamination". 
In article 49 The law also mentioned quarantine types, namely: House quarantine, hospital quarantine, territorial quarantine and social restriction on large scale. The insulation is: "The separation of sick people from healthy people is done in health care facilities to get treatment and care."

Who is authorized to incubation territorial quarantine? It was stated that territorial quarantine restrictions and social restrictions on large scale were established by ministers.

The government has established a task force in the handling of Corona viruses commanded by the head of BNPB. The law has mandated a very strategic situation in certain situations, one level under war emergency to BNPB and BPBD, that is what is called "ease of Access".

In article 55 of Law No. 24 of 2007 on disaster relief is mentioned that:

"In case of disaster emergency status is established, the National Agency for Disaster Management and regional disaster management agency has easy access which includes: human resource deployment, equipment deployment, logistics deployment, immigration, excise, and quarantine, licensing, procurement of goods/services, management and accountability of money and/or goods, rescue, and command to instruct the sector/institution." (UURI, 2007)

\section{RESULTS AND DISCUSSION}

In Indonesia, the people of Corona positively also continue to grow. With the increasing of these sufferers, it has provided a greater negative effect on the education sector in it. To that dampen the impact, it takes strategic steps. It needs to be done by the government quickly and appropriately.

The first thing to do is to educate students and education practitioners. This can be done by intensive socialization by the health department of the Coronavirus itself, both from the prevention aspect as well as the way of dealing with it. This insight is expected to reduce the effect of excess concerns that can cause traumatic impacts on students and of course the teachers.

The second step is to prepare a dedicated team of psychologists to conduct mentoring to the students both collectively and individually, especially to schools located in the affected area of the virus. Most especially for students who fail to do the programs he dreamed of and his stays such as race activities at an international level or comparative study abroad(Duffy \& Scott, 2020).

With this mentoring is expected to relieve their psychological burden and strengthen the spirit of learning. The government has prepared a team of psychologists to conduct assistance with citizens at the quarantine site in Natuna. But, seeing the current deployment conditions, the mentoring needs to be expanded again. At a minimum, encourage every school institution for socialization and mentoring to anticipate more severe impacts.

As for the process of education due to the closure and delay of learning time, it is necessary to prepare a concrete solution anyway. One of the things that can be 
done is with a remote system of learning by utilizing the existing technology. Because if not, then this will harm the development of maturity results and achievement of the education process(BBC, 2020).

\section{Corona Emergency Education policies}

Since President Joko Widodo announced the first case of COVID-199 on March 2, 2020, Indonesia has automatically become one of the countries affected by Coronavirus. The positive casualty contracted Corona reaches 1,414 people, based on an update per 15.45 WIB, March 30, 2020(Kemenkes, 2020).

Among these 1,217 were being treated, 75 had been declared cured, and 122 were declared dead. Some policies were immediately taken by the government to break the COVID-199 spread chain. Here are some policies in the field of education taken by the Government regarding the COVID-19 case(Kemdikbud, 2020).

\section{Online Learning for schoolchildren}

The increased spread of Coronaviruses, making the provincial government quick to take action, one closes the school for two weeks. This step was taken by the provincial government to prevent the spread of Coronaviruses.

Referring to Mendikbud's circular letter No. 3 of 2020 on the prevention of COVID19 on the education unit, and the number 36962/MPK. A/HK/2020, the teaching and learning activities are conducted online to prevent the spread of Corona Virus Disease (COVID-19).

Several local governments have also been in the school to anticipate the spread of the COVID-19. Some of the solutions, school learning is replaced with online learning, or are familiar to be referred to.

Even reportedly, some areas have extended this online learning period up to two months later. One of them was the Tangerang regency, through the Education Office issued a policy of extending students ' study time at home for two months until 23 May 2020.

This policy was taken to suppress the number of transmission of the Corona COVID-19 outbreak. The policy applies to all students of kindergarten, elementary, Junior high and equal in the region. Before that, the school's activities were canceled only for two weeks.

Online learning, according to, the Secretary-general of the Federation of Indonesian Teachers (FSGI) Heru Purnomo, is right, at least from the health side. But for the effectiveness of the learning, he assessed the need for some prepared schools and teacher teachers. According to him, the teacher must be proactive and creative to make teaching activities as effective as face to face. "His strategy must be mapped by the teacher's father and mother. So that is then handed out in the form of a question only, from the observation that means to pursue the target curriculum. This is a home learning that has been in a regular class due to emergency conditions, "he explained. Similarly, the national coordinator of the Indonesian Education Monitoring Network (JPPI), Ubaid Matraji. In addition to teachers, he explained that parents should also monitor their children to study at home. "Learning at home is not a holiday, not that there is no literacy activity. This is to be understood. Keep learning with the targets already in the curriculum, "He explained. Larger challenges will arise if this policy is applied in areas with 
insufficient Internet infrastructure and technologies such as those in villages. "Schools that do not have online learning facilities will have difficulties in pursuing the subject of learning materials," said the researcher from the Center for Indonesian Policy Studies (CIPS) Nadia Fairuza Azzahra by written information. It applies to learners who lack access to technology and the Internet. The only thing that can be done is to give a lot of homework to learners, although this method is not as much as online learning, and is paid for when face-to-face classes are held again. Also, another problem that needs to be considered is, "the students will also have difficulties to consult with the teacher especially for lessons that are considered to require a deeper explanation and understanding, such as mathematics(Saputro et al., 2019; Soewardini et al., 2019). "

The Indonesian Children Protection Commission (KPAI) asked the central and local governments to evaluate the home-study system because the school was dissolved during the COVID-19 outbreak or Coronavirus disease.

KPAI Commissioner of Education, Retno Listyarti assesses the home study system that schools implement is ineffective because there is no good understanding by teachers. Because during the learning policies of the home, many teachers instead gave tasks to accumulate that ended the students becoming stressed(Wangi et al., 2018).

"KPAI received complaints of many parents of students who complained of their children instead of stress because of obtaining various tasks every day from their teachers," he said through a press release received CNNIndonesia.com, Wednesday $(18 / 3)$.

He argues that most teachers interpret home learning by giving assignments online, and having students gather assignments every day.

\section{Online Courses}

Most universities in Indonesia have implemented a long-distance class or an online class, as an actor on the spread of the Corona COVID-19 virus. In addition to learning and teaching, several campuses in the country have taken the policy until the end of the even semester so that all coursework activities are done online, including mid-semester exams, semester final examinations, Practicums, and finalduty guidance, theses, and dissertations.

This decision is taken under consideration of the current Coronavirus spread condition at the national level which is getting worse. During online learning, students and lecturers are asked to conduct learning activities using online applications such as video conferencing applications, e-mail, and online social media(Kurniasih et al., 2018).

\section{National Exam 2020 Cancelled}

President in the limited meeting held on Tuesday (24/3) with the related ministers, has been decided. As a result, the government announced the National Exam (UN) this year was officially abolished. Starting from elementary school (SD) level to high school level (SMA). 
These measures were taken as part of the COVID-19 pandemic response system, to prioritize the safety and health of the people. Government policy negates the UN, according to Fadjroel, must be greeted with the active participation of citizens in the application of physical distancing behavior. As per the Nets, work from home, learn from home and worship at home.

Related to the omission of UN, Mendikbud Nadiem Makarim one vote with the Ministry of Education and Culture (Kemendikbud) has cooperates with Commission X DPR RI to discuss the replacement of UN. There are two options, conducting a national standard school exam (USBN) online or applying a graduation method by weighing the cumulative value of students while studying in the school.

The option to eliminate UN for middle school, Elementary and Madrasah will also be taken if the school guarantees to organize the USBN online. This means that about 1 million high school students, SMK, Junior High, and Madrasah will solve the UN in their homes.

\section{UTBK SBMPTN 2020 Postponed}

The College Admission Test (LTMPT) issued a policy of postponing registration and implementation of a computer-based writing exam (UTBK) 2020. It is channeled due to the global pandemic COVID-19 which has entered Indonesia.

Not only the registration and implementation of the first phase of the UTBK were postponed, but the second stage registration of UTBK 2020 was also postponed. For the latest info about the implementation of UTBK SBMPTN, 2020 will be given further later when the situation has been recovered.

\section{The implementation of SNMPTN still in the assessment}

The new policy was delivered by the chairman of the University Entrance Test Institute (LTMPT), Mohammad Nasih (21/3). He explained, there are some considerations until the announcement of graduation was postponed. Among other things, there is still a period of data replenishment of the Indonesia Smart card registration number (KIP) which is held from 2 to 31 March.

\section{CONCLUSION}

The Indonesian Government has stated that it will give the best and most maximal effort in dealing with corona or COVID-19 viruses. The government is a real present to protect its citizens in a strong and secure the safety of every citizen. The Government's efforts deserve the support of all Indonesians. Because with unity, collaboration and Synergy, Indonesia believes it can solve the problem of deployment of COVID-19. In the field of education, the government issued some of the policies facing Coronavirus. This is all done to minimize the spread of coronaviruses. 


\section{Suggestion}

The people of Indonesia are expected to remain calm and do not give an excessive reaction and promote clean and healthy living to prevent the transmission of COVID-19. The public is also encouraged to restrict unnecessary publications and to not disseminate information that is in the junction, lies or hoaxes related to the Coronavirus that could cause community panic.

\section{REFERENCES}

Babic, B., Gerke, S., Evgeniou, T., \& Glenn Cohen, I. (2019). Algorithms on regulatory lockdown in medicine. Science. https://doi.org/10.1126/science.aay9547

Bair, A. (2002). Book Review: Lockdown America: Police and Prisons in the Age of Crisis. Review of Radical Political Economics. https://doi.org/10.1177/048661340203400324

BBC. (2020). Experts are saying it could actually be more dangerous to close schools.

Board, T. E. (2020). Is the World Ready for the Coronavirus?-Distrust in science and institutions could be a major problem if the outbreak worsens. The New York Times. https://www.nytimes.com/2020/01/29/opinion/coronavirusoutbreak.html

Chen, H., Guo, J., Wang, C., Luo, F., Yu, X., Zhang, W., Li, J., Zhao, D., Xu, D., Gong, Q., Liao, J., Yang, H., Hou, W., \& Zhang, Y. (2020). Clinical characteristics and intrauterine vertical transmission potential of COVID-19 infection in nine pregnant women: a retrospective review of medical records. The Lancet. https://doi.org/10.1016/S0140-6736(20)30360-3

Cruz, J. L. G., Sola, I., Becares, M., Alberca, B., Plana, J., Enjuanes, L., \& Zuñiga, S. (2011). Coronavirus gene 7 counteracts host defenses and modulates virus $\begin{array}{llll}\text { virulence. PLoS Pathogens, } & \text { 7(6), } & \end{array}$ https://doi.org/10.1371/journal.ppat.1002090

Duffy, C., \& Scott, S. (2020). Should I keep my children home from school due to coronavirus? - ABC News (Australian Broadcasting Corporation). https://www.abc.net.au/news/2020-03-16/should-i-keep-my-childrenhome-from-school-due-to-coronavirus/12058200

EdgeProp. (2020). COVID-19: International Islamic University Malaysia cancels classes / EdgeProp.my. https://www.edgeprop.my/content/1644595/covid19-international-islamic-university-malaysia-cancels-classes

Gao, J., Tian, Z., \& Yang, X. (2020). Breakthrough: Chloroquine phosphate has shown apparent efficacy in treatment of COVID-19 associated pneumonia in clinical studies. BioScience Trends. https://doi.org/10.5582/bst.2020.01047

Geller, C., Varbanov, M., \& Duval, R. E. (2012). Human coronaviruses: Insights into environmental resistance and its influence on the development of new antiseptic strategies. In Viruses (Vol. 4, Issue 11, pp. 3044-3068). https://doi.org/10.3390/v4113044

Hageman, J. R. (2020). The coronavirus disease 2019 (COVID-19). In Pediatric Annals. https://doi.org/10.3928/19382359-20200219-01

Handoyo. (2020). UNESCO: Wabah virus corona ancam pendidikan 300 juta siswa. 2020. https://internasional.kontan.co.id/news/unesco-wabah-virus-corona- 
ancam-pendidikan-300-juta-siswa

Jones, N. M., Thompson, R. R., Schetter, C. D., \& Silver, R. C. (2017). Distress and rumor exposure on social media during a campus lockdown. Proceedings of the National Academy of Sciences of the United States of America. https://doi.org/10.1073/pnas.1708518114

Kemdikbud. (2020). Kementerian Pendidikan dan Kebudayaan » Republik Indonesia. https://www.kemdikbud.go.id/main/blog/2020/03/se-mendikbudpencegahan-dan-penanganan-corona-virus-disease-covid19-di-kemendikbud

Kemenkes. (2020). Home» Info Infeksi Emerging Kementerian Kesehatan RI. https://infeksiemerging.kemkes.go.id/

Kim, M. J., \& Denyer, S. (2020). Coronavirus gives kids in South Korea a break from school pressures? but also traps them - The Washington Post. https://www.washingtonpost.com/world/asia_pacific/in-south-koreacoronavirus-gives-kids-a-break-from-school-pressures-but-also-trapsthem/2020/02/27/713424f6-5896-11ea-8efd-0f904bdd8057_story.html

Kurniasih, N., Rhefhansha, R. F., Wajdi, M. B. N., Haluti, A., Sari, D. A. P., Manurung, R. T., \& Mudjanarko, S. W. (2018). Internet and learning resources: a case study of the Library and Information Science Students at Universitas Padjadjaran. Journal of Physics: Conference Series, 1114(1), 12086.

Laboratory testing of human suspected cases of novel coronavirus (nCoV) infection. Interim guidance, 10 January 2020. (n.d.). Retrieved April 6, 2020, from https://apps.who.int/iris/bitstream/handle/10665/330374/WHO-2019nCoV-laboratory-2020.1-eng.pdf

Masters, P. S. (2006). The Molecular Biology of Coronaviruses. In Advances in Virus Research (Vol. 65, pp. 193-292). https://doi.org/10.1016/S00653527(06)66005-3

Novel coronavirus infection. (2013). World Health Association. http://www.who.int/csr/don/2013_05_22_ncov/en/index.html

Palu, T. (2020). UNESCO Catat Ada 113 Negara yang Tutup Fasilitas Pendidikan Pasca Mewabahnya Virus Corona - Tribun Palu. 2020. https://palu.tribunnews.com/2020/03/18/unesco-catat-ada-113-negarayang-tutup-fasilitas-pendidikan-pasca-mewabahnya-virus-corona

Saputro, S. H., Lestari, V. N. S., Suhaemi, I., Rodli, F., Prasnowo, M. A., Wajdi, M. B. N., Noordyana, M. A., \& Permatasari, F. (2019). Utilization of Whatsapp Application as Communication Media in Language Teaching and Learning at FBS UWKS. Journal of Physics: Conference Series, 1175(1), 12262.

Sexton, N. R., Smith, E. C., Blanc, H., Vignuzzi, M., Peersen, O. B., \& Denison, M. R. (2016). Homology-Based Identification of a Mutation in the Coronavirus RNADependent RNA Polymerase That Confers Resistance to Multiple Mutagens. Journal of Virology, 90(16), 7415-7428. https://doi.org/10.1128/jvi.00080-16

Shira, D. (2020). China Extends Lunar New Year Holiday to Feb 2, Shanghai to Feb 9. https://www.china-briefing.com/news/china-extends-lunar-new-yearholiday-february-2-shanghai-february-9-contain-coronavirus-outbreak/

Soewardini, H. M. D., Supratiwi, R. A., Serin, A., Hoesny, M. U., Wajdi, M. B. N., Hastuti, S., Setiawan, A., Gaol, E. L., \& Christie, C. D. Y. (2019). Mathematical Comics on Class X Trigonometry Learning. Journal of Physics: Conference Series, 1175(1), 12013. 
Sturman, L. S., \& Holmes, K. V. (1983). The molecular biology of coronaviruses. Advances in Virus Research, 28(C), 35-112. https://doi.org/10.1016/S00653527(08)60721-6

Sun, P., Lu, X., Xu, C., Sun, W., \& Pan, B. (2020). Understanding of COVID-19 based on current evidence. In Journal of Medical Virology. https://doi.org/10.1002/jmv.25722

Touret, F., \& de Lamballerie, X. (2020). Of chloroquine and COVID-19. In Antiviral Research. https://doi.org/10.1016/j.antiviral.2020.104762

UNESCO. (2020). Events canceled/postponed - Coronavirus Outbreak. 2020. https://en.unesco.org/events/events-canceledpostponed-coronavirusoutbreak

UURI. (2007). Undang-undang republik indonesia nomor 24 tahun 2007 tentang penanggulangan bencana.

UURI. (2018). UU No. 6 Tahun 2018 tentang Kekarantinaan Kesehatan [JDIH BPK RI]. https://peraturan.bpk.go.id/Home/Details/90037/uu-no-6-tahun-2018

Velavan, T. P., \& Meyer, C. G. (2020). The COVID-19 epidemic. In Tropical Medicine and International Health. https://doi.org/10.1111/tmi.13383

Wangi, N. B. S., Nashrullah, M. H., \& Wajdi, M. B. N. (2018). Digital Era's Education and Aplication in Higher Education. EDUTEC: Journal of Education And Technology, 1(2), 119-128.

Weil, K. M. (2003). Lockdown. AJN, American Journal of Nursing. https://doi.org/10.1097/00000446-200304000-00039

WHO. (2020). Coronavirus. https://www.who.int/healthtopics/coronavirus\#tab=tab_1

Zheng, Y. Y., Ma, Y. T., Zhang, J. Y., \& Xie, X. (2020). COVID-19 and the cardiovascular system. In Nature Reviews Cardiology. https://doi.org/10.1038/s41569-0200360-5 